\title{
Archetypal kimberlite from the Maniitsoq region, southern West Greenland and analogy to South Africa
}

\author{
Troels F.D. Nielsen, Martin Jebens, Sven M. Jensen \& Karsten Secher
}

Ultramafic dyke rocks with kimberlitic megacrysts and mantle nodules have been known for decades from the northern part of the Archaean block and adjacent Proterozoic terranes in southern West Greenland (Fig. 1; Escher \& Watterson 1973; Goff 1973; Scott 1981; Larsen \& Rex 1992; Mitchell et al. 1999). Some of the dykes have proved to be diamondiferous (see Jensen et al. 2004a, b, for exploration results, diamond contents, and references). The $c .600 \mathrm{Ma}$ old dykes were called 'kimberlitic' by Larsen \& Rex (1992), but Mitchell et al. (1999) concluded that they were best referred to a 'carbonatiteultramafic lamprophyre' suite (aillikites or melnoites). Mitchell et al. (1999) further suggested that the West Greenland province represents "one of the few bona fide examples of ultramafic lamprophyre which contain diamonds".

Reports on indicator mineral assemblages (Jensen et al. 2004b) and diamond contents (e.g. Hudson Resources Inc. 2005) have re-opened the discussion on the classification of the dykes. The results of an investigation of the Majuagaa dyke (Nielsen \& Jensen 2005) are summarised below, together with the preliminary results of a regional investigation of the groundmass minerals of the dykes. It is concluded that dykes in the Maniitsoq region are similar to archetypal, South African, on-craton, Type 1 kimberlites, and that all regions of the West Greenland province of ultramafic magmatism are favourable for diamond exploration.

\section{The Majuagaa dyke}

The Majuagaa dyke (Jensen et al. 2004a) is $2.5 \mathrm{~km}$ long and up to $2 \mathrm{~m}$ wide. It is located $c .50 \mathrm{~km} \mathrm{SSE}$ of Maniitsoq (Fig. 1) and strikes WSW-ENE. The dyke is dark grey with many olivine-rich fragments (up to $10 \mathrm{~cm}$ ) and rounded megacrysts of ilmenite (up to $4 \mathrm{~cm}$ ). It contains the classic kimberlitic suites of megacrysts and mantle nodules, including eclogite (Jensen \& Secher 2004, fig. 5). The groundmass is fine-grained and composed of olivine fragments, calcite, serpentine, ilmenite and minor Mg-rich spinel. Phlogopite and apatite are rare. The dyke is diamondiferous (Jensen et al. 2004a).

Samples were collected along the length of the dyke. Sixty thin sections (Fig. 2) were examined and a number selected for an electron microprobe study. All mineral data from groundmass, megacysts and nodules, the bulk chemistry, and analytical techniques are reported in Nielsen \& Jensen (2005).

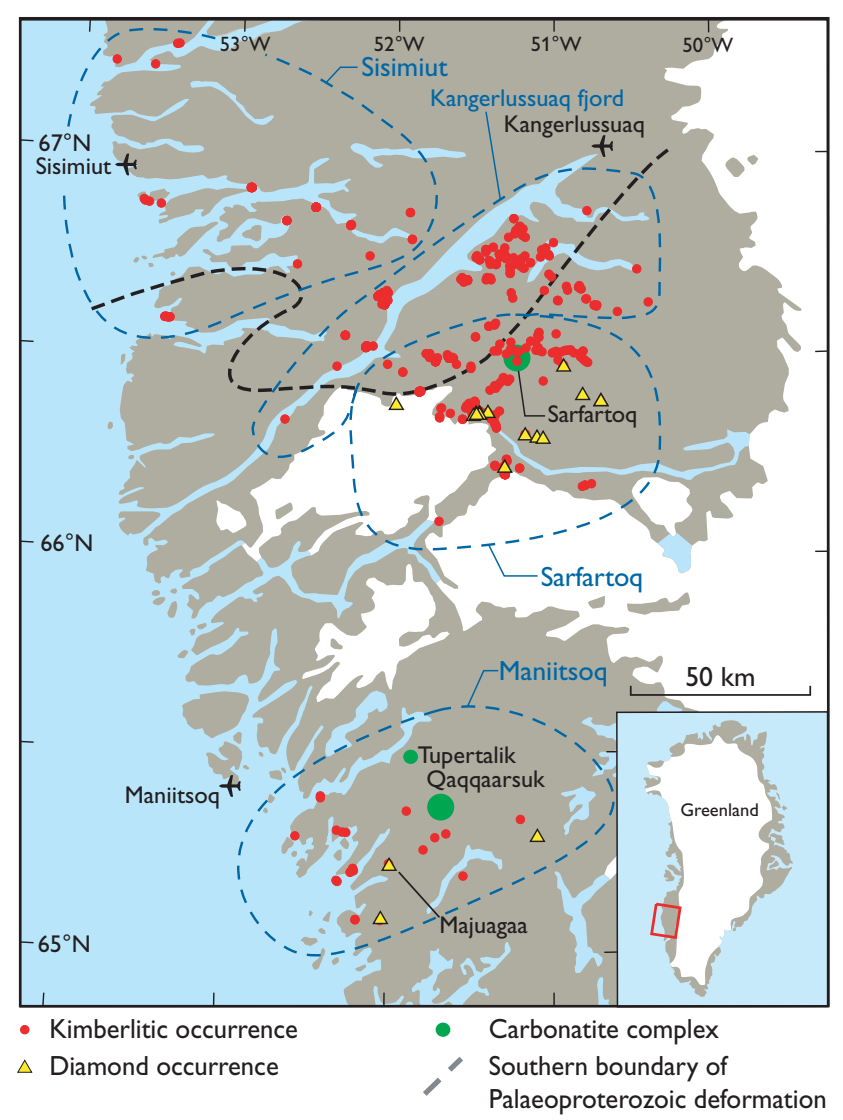

Fig. 1. Kimberlites and ultramafic lamprophyres (kimberlitic occurrences), carbonatite complexes and diamond occurrences in southern West Greenland (after Jensen \& Secher 2004). Regions are indicated.

\section{Classification of the Majuagaa dyke}

Mitchell (1995) and Tappe et al. (2005) use the following criteria for the classification of kimberlite (s.s.): (1) the groundmass contains no clinopyroxene; (2) groundmass spinel belongs to the Magmatic Trend 1 (Mg-rich titanomagnetite); (3) phlogopite is zoned towards the $\mathrm{Al}_{2} \mathrm{O}_{3}$ - and $\mathrm{BaO}$-rich kinoshitalite endmember and (4) ilmenite has a high geikilite component (> $40 \mathrm{~mol} . \% \mathrm{MgTiO}_{3}$ ) and little pyrophanite $\left(\mathrm{MnTiO}_{3}\right)$. Mitchell et al. (1999) found that these criteria were not met by the West Greenland dykes and concluded they were ultramafic lamprophyres (aillikites or melnoites) rather than kimberlites. 


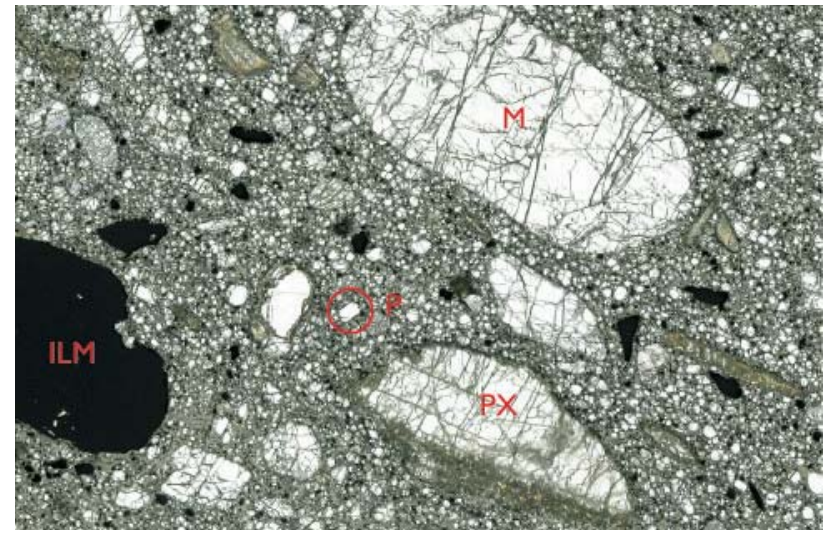

Fig. 2. Plain polarised photograph of thin section $(22 \times 40 \mathrm{~mm})$ from the Majuagaa kimberlite. The rock is composed of fragments of olivine, ilmenite and pyroxene from disintegrated megacrysts and nodules in a groundmass of calcite, serpentine, spinel and ilmenite and rare phlogopite and apatite. Only a single olivine microphenocryst is observed (P). $\mathbf{M}$ : olivine megacryst; PX: fragment of clinopyroxene megacryst and ILM: ilmenite megacryst.

Nielsen \& Jensen (2005) made the following observations in the Majuagaa dyke:

- The clinopyroxene criteria: No clinopyroxene was found in the groundmass.

- The Magmatic Trend 1 spinel criteria: The cores of euhedral spinel grains ( $<0.1 \mathrm{~mm}$ across) have compositions in the Magmatic Trend 1 field (Fig. 3). Mg-rich rims compare with spinels of South African calcite-kimberlite (Mitchell et al. 1999).

- The ilmenite criteria: Groundmass grains conform with the compositions from archetypal kimberlite (Fig. 4), whereas megacrysts appear to be xenocrystic (Nielsen \& Jensen 2005).

- The phlogopite criteria: Tiny, euhedral, clear to weakly greenish flakes are rich in $\mathrm{Al}_{2} \mathrm{O}_{3}$ and $\mathrm{BaO}$ (Fig. 5), poor in $\mathrm{TiO}_{2}$ and $\mathrm{FeO}$ (total) and rich in the kinoshitalite end member. They conform with phlogopite of archetypal kimberlite (see Mitchell 1995).

\section{Majuagaa bulk composition}

The bulk composition of the Majuagaa dyke is kimberlitic (see Nielsen \& Jensen 2005). The average REE (Fig. 6) and trace element (Fig. 7) compositions of the Majuagaa dyke folow the base of the fields of Kimberley (South Africa), oncraton, Type 1 kimberlites (Le Roex et al. 2003). The

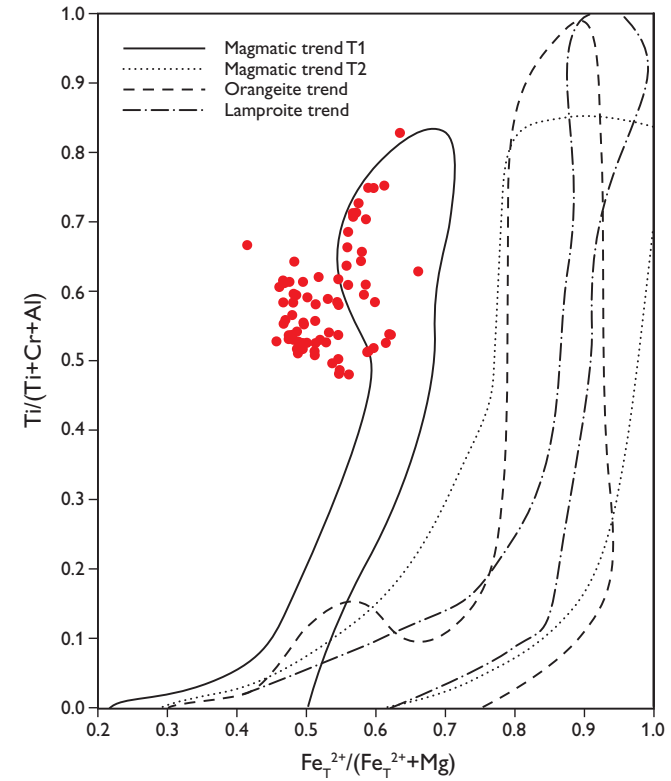

Fig. 3. Cores of groundmass spinels plot in the field of the Magmatic Trend 1 spinels of archetypal kimberlites (after Nielsen \& Jensen 2005). Rim compositions to the left of the field are characteristic of calcite kimberlites (Mitchell 1995). All other fields after Mitchell (1995).

Majuagaa dyke shows positive $\mathrm{Ti}-, \mathrm{Nb}-$ and $\mathrm{Ta}$-anomalies. They are caused by a high proportion of ilmenite megacrysts. In mineralogy (see above) as well as bulk chemistry the Majuagaa dyke is best compared to classic South African, oncraton, Type 1 kimberlite.

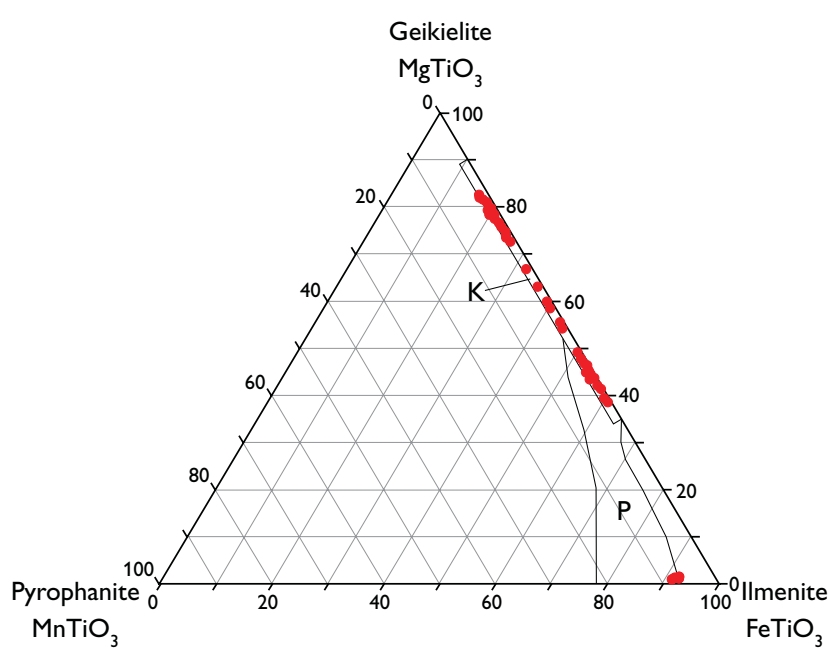

Fig. 4. Proportions of ilmenite endmembers of the Majuagaa dyke. Fields for kimberlite and Premier Mine kimberlite (P) from South Africa are shown (after Nielsen \& Jensen 2005). 


\section{Regional variations}

The West Greenland province is part of the $c .600 \mathrm{Ma}$ old North Atlantic province of carbonatite and ultramafic alkaline magmatism, from the Torngat region (Canada) to the Archaean of West Greenland (Tappe et al. 2004). The compositions of groundmass phlogopite reflect the compositions of the melts (Mitchell 1995). The preliminary results of a regional investigation (Fig. 8) suggest a gradual evolution from oncraton, South African Type 1 kimberlite in the West Greenland Archaean craton (Maniitsoq), through a kimberlite/ultramafic lamprophyre (kimberlite/aillikite) zone at the border between Archaean and Proterozoic terranes (Sarfartoq and along the Kangerlussuaq fjord, Fig. 1) to ultramafic lamprophyre (aillikite/melnoite) magmatism in the Proterozoic terranes of Sisimiut (Greenland; Scott 1977) and Torngat (Canada; Tappe et al. 2004).

\section{The diamond potential}

Results of Hudson Resources Inc. (2005) suggest that stones of gem quality and size may be found in West Greenland. Nevertheless, it appears to be an issue for some exploration companies and investors that Mitchell et al. (1999) classified the West Greenland dykes as ultramafic lamprophyres and implied that true kimberlite was not found.

However, the Majuagaa dyke documents that diamondiferous, archetypal Type 1 kimberlite occurs in the West Greenland province. Hutchison (2005) describes the best investigated and most promising West Greenland diamond occurrence at 'Garnet Lake' (border zone; Sarfartoq region, Fig. 1). The 'Garnet Lake' dykes have characteristics of both kimberlite and ultramafic lamprophyre and have features reminiscent of South African orangeite. Finally, the ultramafic lamprophyres (aillikites/melnoites) of the Proterozoic Sisimuit region compare with diamondiferous ultramafic lamprophyres (aillikites) of the Torngat region (Fig. 8; Tappe et al. 2004), and a diamond potential is also indicated in the little prospected Sisimiut region.

\section{Conclusions}

The c. $600 \mathrm{Ma}$ old ultramafic magmatism of the West Greenland province shows - from the Archaean craton to the Proterozoic terranes - a transition from classic South African, on-craton Type 1 kimberlite to ultramafic lamprophyre (aillikite/melnoite). Diamonds are recovered from the entire range and a diamond potential thus exists throughout the West Greenland province.

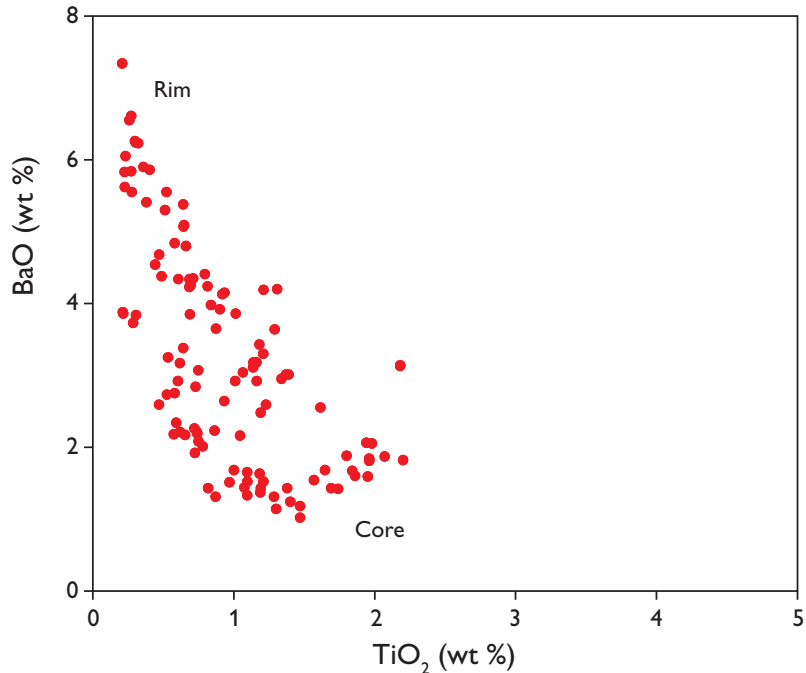

Fig. 5: $\mathrm{BaO}$ vs. $\mathrm{TiO}_{2}$ in groundmass phlogopite of the Majuagaa dyke showing the general increase in $\mathrm{BaO}$ and decrease in $\mathrm{TiO}_{2}$ in the margins of the grains (after Nielsen \& Jensen 2005)

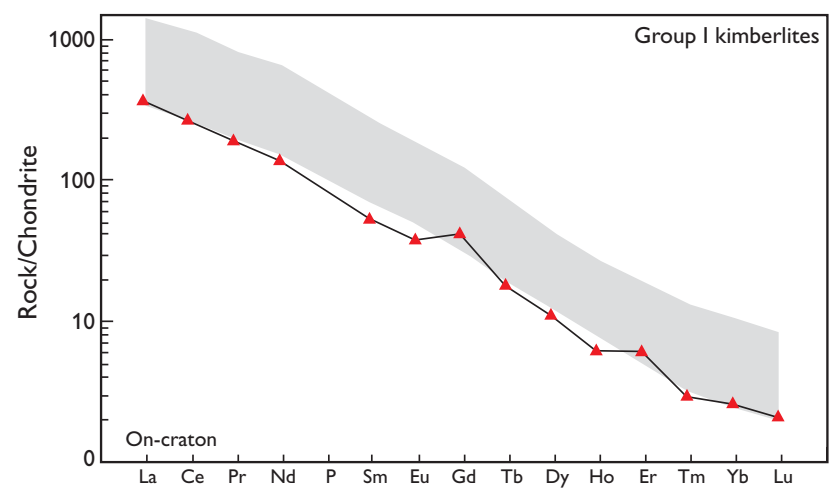

Fig. 6. Chondrite normalised bulk REE concentrations of the Majuagaa dyke (after Nielsen \& Jensen 2005). Grey field: Kimberley (South Africa), Type 1 kimberlites (Le Roex et al. 2003).

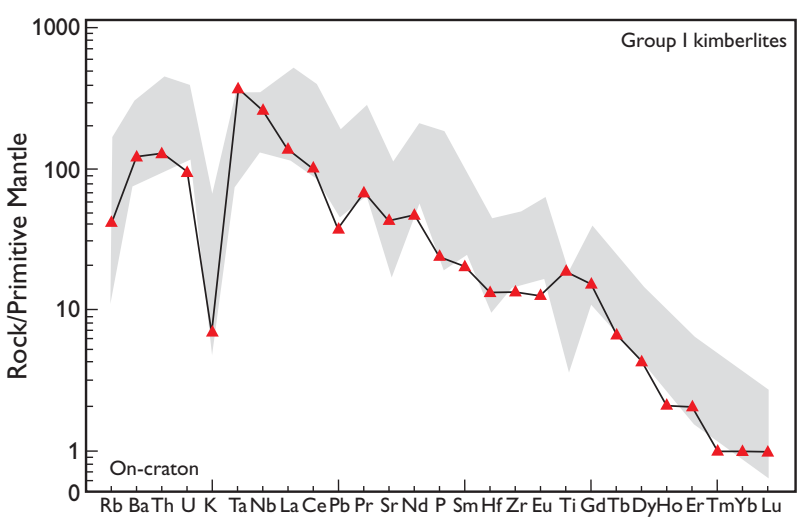

Fig. 7. Trace element concentrations of the Majuagaa dyke normalised to primitive mantle (after Nielsen \& Jensen 2005). Grey field: Kimberley (South Africa), Type 1 kimberlites (Le Roex et al. 2003). 


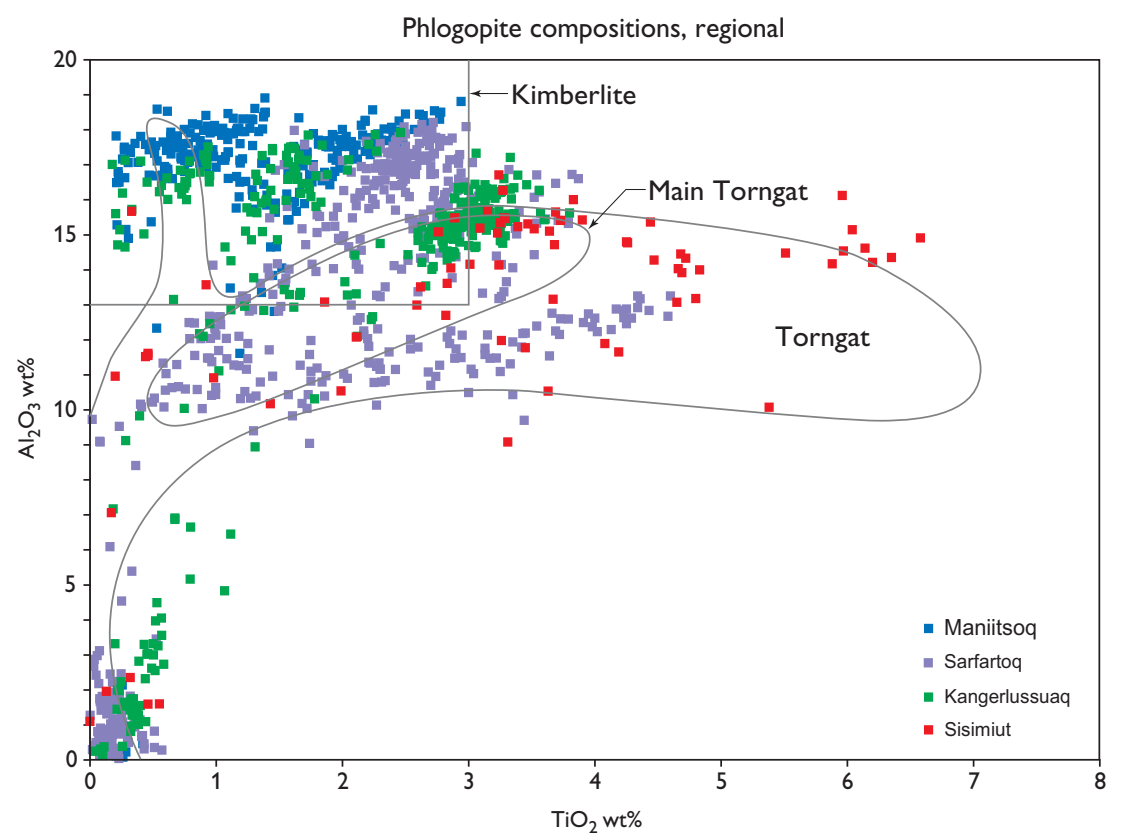

Fig. 8. $\mathrm{Al}_{2} \mathrm{O}_{3}$ vs. $\mathrm{TiO}_{2}$ of groundmass phlogopites from the Maniitsoq (Archaean craton), Sarfartoq and Kangerlussuaq fjord (border zone to the Proterozoic) and Sisimiut (Proterozoic) regions. The Sisimiut data (Scott 1977) includes one locality referred to the border zone. Kimberlite box in top-left corner after Mitchell (1995). Torngat field after Tappe et al. (2004).

\section{Acknowledgements}

The investigation was carried out under contract with the Bureau of Minerals and Petroleum (BMP), Nuuk, Greenland.

\section{References}

Escher, A. \& Watterson, J. 1973: Kimberlites and associated rocks in the Holsteinsborg - Søndre Strømfjord region, central West Greenland. Rapport Grønlands Geologiske Undersøgelse 55, 26-27.

Goff, S.P. 1973: The mineralogy and mineral chemistry of a kimberlite dike from Søndre Isortoq fjord, south-west Greenland, 103 pp. Unpublished Ph.D. thesis, University of Leicester, United Kingdom.

Hudson Resources Inc. 2005: Hudson finds larger diamonds at Garnet Lake and confirms new diamond area. Web release, December 1, 2005 (info@hudsonresources.ca)

Hutchison, M.T. 2005: Diamondiferous kimberlites from the Garnet Lake area, West Greenland: exploration, methologies and petrochemistry. In: Secher, K. \& Nielsen, M.N. (eds): Workshop on Greenland's diamond potential, 7-9 November 2005, in Copenhagen. Danmarks og Grønlands Geologiske Undersøgelse Rapport 2005/68, 33-42.

Jensen, S.M. \& Secher, K. 2004: Investigating the diamond potential of southern West Greenland. Geological Survey of Denmark and Greenland Bulletin 4, 69-72.

Jensen, S.M., Secher, K. \& Rasmussen, T.M. 2004a: Diamond content of three kimberlitic occurrences in southern West Greenland. Diamond identification results, field description and magnetic profiling. Danmarks og Grønlands Geologiske Undersøgelse Rapport 2004/19, 41 pp.

Jensen, S.M., Secher, K., Rasmussen, T.M. \& Schjøth, F. 2004b: Diamond exploration data from West Greenland: 2004 update and revision. Danmarks og Grønlands Geologiske Undersøgelse Rapport 2004/117, 90 pp. (1 DVD enclosed).
Larsen, L.M. \& Rex, D.C. 1992: A review of 2500 Ma span of alkaline, ultramafic, potassic and carbonatitic magmatism in West Greenland. Lithos 28, 367-402.

Le Roex, A.P., Bell, D.R. \& Davis, P. 2003: Petrogenesis of group 1 kimberlites from Kimberley, South Africa: evidence from bulk-rock geochemistry. Journal of Petrology 31, 779-812.

McDonough, W.F. \& Sun, S.-S. 1995: The composition of the Earth. Chemical Geology 120, 223-253.

Mitchell, R.H. 1995: Kimberlites, orangeites and relates rocks, 410 pp. New York / London: Plenum Press.

Mitchell, R.H., Scott Smith, B.H. \& Larsen, L.M. 1999: Mineralogy of ultramafic dikes from the Sarfartoq, Sisimiut and Maniitsoq areas, West Greenland. In: Gurney, J.J. et al. (eds): Proceedings of the Vita International Kimberlite Conference 2, 574-583. Cape Town: Red Roof Design.

Nielsen, T.F.D. \& Jensen, S.M. 2005: The Majuagaa calcite-kimberlite dyke, Maniitsoq, southern West Greenland. Danmarks og Grønlands Geologiske Undersøgelse Rapport 2005/43, 59 pp.

Scott, B.H. 1977: Petrogenesis of kimberlites and associated potassic lamprophyres from central West Greenland, 133 pp., + 6 appendices. Unpublished Ph.D. thesis, University of Edinburgh, United Kingdom. Scott, B.H. 1981: Kimberlite and lamprophyre dykes from Holsteinsborg, West Greenland. Meddelelser om Grønland. Geoscience 4, 24 pp.

Tappe, S., Jenner, G.A., Foley, S.F., Heaman, L.M., Besserer, D., Kjarsgaard, B.A. \& Ryan, A.B. 2004: Torngat ultramafic lamprophyres and their relation to the North Atlantic alkaline province. Lithos 76, 491-518.

Tappe, S., Foley, S.F., Jenner, G.A. \& Kjarsgaard, B.A. 2005: Integrating ultramafic lamprophyres into the IUGS classification of igneous rocks: rational and implications. Journal of Petrology 46, 1893-1900.

\footnotetext{
Authors' address

Geological Survey of Denmark and Greenland, Øster Voldgade 10, DK-1350 Copenhagen K, Denmark. E-mail: tfn@geus.dk
} 


\title{
Using zircon geochronology to resolve the Archaean geology of southern West Greenland
}

\author{
Julie A. Hollis, Dirk Frei, Jeroen A.M. van Gool, Adam A. Garde and Mac Persson
}

Until recently, in situ U-Pb zircon geochronology could be carried out only using ion microprobes, requiring lengthy analysis times of c. 20 minutes. However, new developments in laser ablation inductively coupled plasma mass spectrometer technologies have resulted in zircon geochronology techniques that are much faster, simpler, cheaper, and more precise than before (e.g. Frei et al. 2006, this volume). Analyses approaching the precision obtained via ion microprobe can now be undertaken in 2-4 minutes using instruments such as the $213 \mathrm{~nm}$ laser ablation (LA) system coupled with Element 2 sector-field inductively coupled plasma mass spectrometer (SF-ICP-MS) housed at the Geological Survey of Denmark and Greenland (GEUS). The up to tenfold decrease in analytical time means that zircon geochronology can now be used in a much wider range of studies.

The Godthåbsfjord region, southern West Greenland, contains some of the oldest rocks exposed on the Earth's surface reflecting a very complex Archaean geological evolution (Figs 1, 2). Over recent years GEUS has undertaken a range of mapping projects at various scales within the Godthåbsfjord region (see also below). These include the mapping of the 1:100 000 scale Kapisillit geological map sheet (Fig. 1), and regional and local investigations of the environments of formation and geological evolution of supracrustal belts, hosting potentially economic mineral occurrences.

Zircon geochronology is an important tool for investigating a range of geological problems in this region. By breaking down the complex geology into a series of simple problems that can be addressed using this tool, the geological evolution can be unlocked in a stepwise manner. Three examples are presented below: (1) the mapping of regional structures; (2) characterising and correlating supracrustal belts; and (3) dating metamorphism and mineralisation. Although focus is on the application of zircon geochronology to these problems, it is important to note that the resulting data must always be viewed within a wider context incorporating geological mapping and structural, geochemical and petrographic investigations.

\section{Regional geology}

The geology of the Godthåbsfjord region is dominated by orthogneiss formed during several distinct episodes of crustal growth during the Archaean (Fig. 2). These different-aged gneisses are thought to represent distinct small continental blocks that were amalgamated during the Neoarchaean (at
Fig. 1. Overview map of the Godthåbsfjord region. Inset shows the location of the main map in Greenland. Supracrustal belts are shown in green. The boundaries of the 1:100 000 scale Kapisillit geological map sheet area are in red. Blue lines outline the area shown in Fig. 3. Bold black lines are inferred terrane boundaries, with the major age components of the different terranes indicated (after Friend \& Nutman 2005).

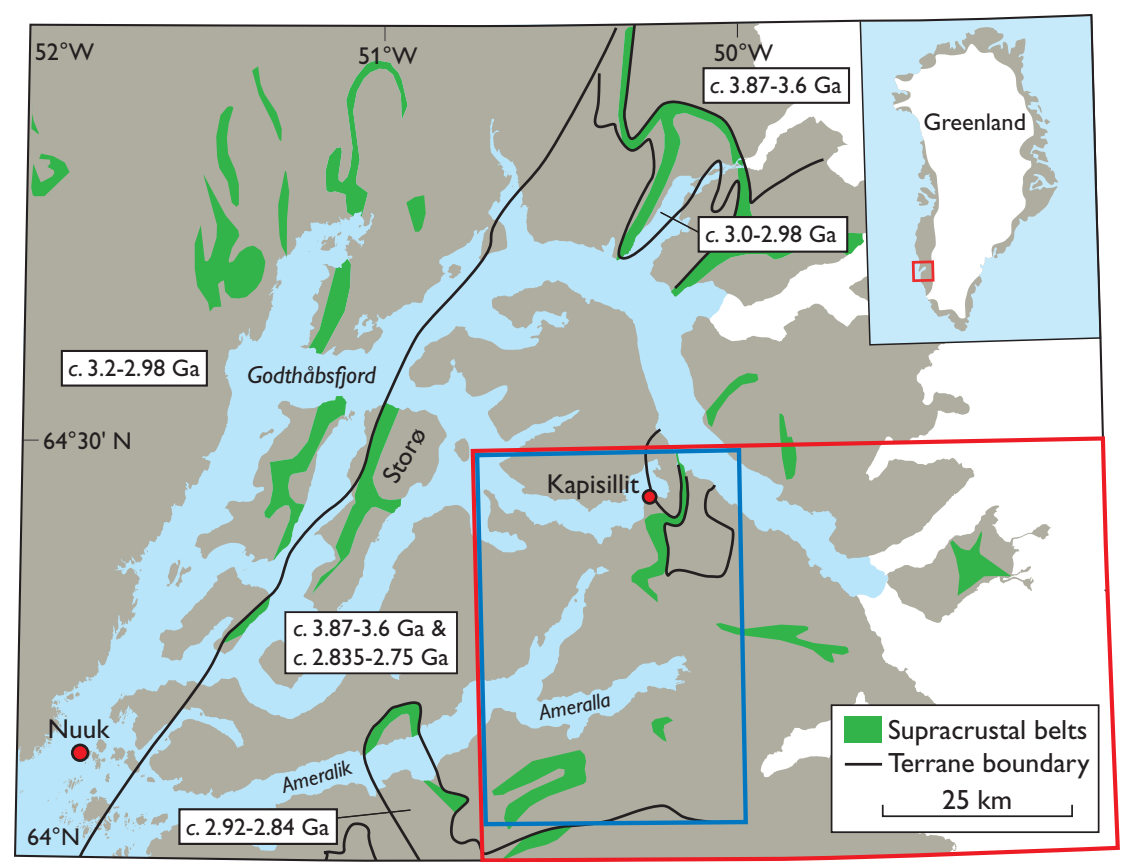

